\title{
Clap, Clap, Clap, ...
}

\author{
Nancy Anderson
}

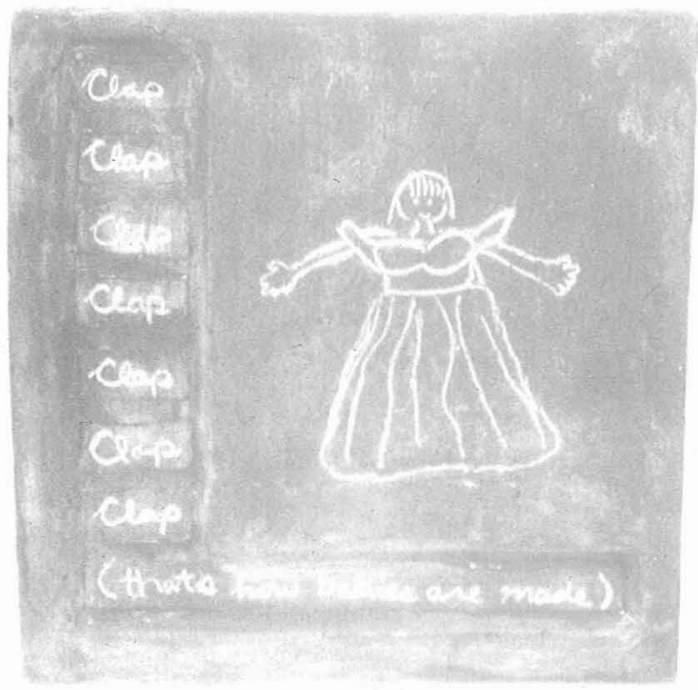

1998 (6" x 8") (plaster, ink, pastel) 